\title{
A Study of The Bacteriological Profile of Chronic Suppurative Otitis Media In Tertiary Facility of Moinabad Belt (Rangareddy District, Telangana State, India)
}

\author{
Dr.S.Indira Devi ${ }^{1}$, Dr. Juveria Majeed ${ }^{2}$, Dr. P. Ramakrishnaiah ${ }^{3}$, \\ Dr. N. Radhakrishna ${ }^{4}$, Dr. R. Vijaykumar ${ }^{5}$ \\ ${ }^{I}$ Head of Department and Professor, Dept. of ENT Head and Neck Surgery, BhaskarMedical College. \\ ${ }^{2}$ Senior Resident, Dept. of ENT Head and Neck Surgery, Bhaskar Medical College. \\ ${ }^{3}$ Assistant Professor, Dept. of ENT Head and Neck Surgery, Bhaskar Medical College. \\ ${ }^{4,5}$ Professor, Dept. of ENT Head and Neck Surgery, Bhaskar Medical College.
}

\begin{abstract}
:
Introduction:

Chronic suppurative otitis media is one of the most common infectious disease worldwide. Also its known for its recurrence and persistence despite adequate treatment. It is caused by a wide variety of microorganisms, both aerobic and anerobic. To add on to it, there is emergence of specific antibiotic resistance due to inadvertent use of these drugs.

Aims And Objectives Of The Study: This study is a hospital based study aimed at re-evaluating the current bacteriological profile of chronic suppurative otitis media (CSOM) and the sensitivity pattern to most of the currently available antibiotics.

Patients And Methods: A total of 100 patients were selected presenting with actively discharging ear or ears to ENT OPD at Bhaskar Medical College/General Hospital, Yenkapally village, Rangareddy district covering 26 villages of moinabad belt. A sterile aural swab with pus was collected and sent for culture of the organism and antibiogram pattern to microbiology department of the same hospital.

Results: We analysed a total of 100 ear swabs ranging from age 1 year to 70 yrs. The most common organism isolated were gram negative organism and among that highest was pseudomonas aeruginosa (25\%), followed very closely by Staphylococcus aureus (24\%) and no organism isolated in $24 \%$ of the cases. The most effective antibiotic overall was found to be Ciprofloxacin in this study, followed closely by Amikacin, Gentamycin and Cefaperazone + sulbactum.Least sensitivity for drugs like Ampicillin and Amoxycillin+ Clavulinic acid.

Conclusions: The judicious use of antibiotics to prevent rapidly emerging resistance to various antibiotics and to prevent morbidity associated with the chronic discharging ear is the reason for knowing antibiogram before starting the treatment. Hence is the study done to know the etiology and antibacterial susceptibility of microorganisms would contribute to a rational antibiotic use and the success of treatment for chronic supportive otitis media.
\end{abstract}

Keywords: Antibiogram, Drug resistance, Chronic Suppurative Otitis media, Pseudomonas Aeroginosa, Staphylococcus aureus.

\section{Introduction}

Chronic suppurative otitis media is one of the most common infectious disease worldwide characterized by a permanent tympanic membrane perforation with persistant or recurrent ear discharge. ${ }^{1,2}$ It is the chronic inflammation of the middle ear cleft lasting for more than 6 weeks. It is basically divided into mucosal or tubotympanic disease or safe type and squamous or atticoantral disease or the unsafe type. ${ }^{3,4}$ The latter type is more commonly associated with complications, intracranial and extracranial. Complications associated with CSOM were frequent in pre-antibiotic era, however, the introduction of antibiotics gave clinicians a tool to be used even without the precise etiological diagnosis and the irrational use of antibiotics led to the emergence of multi-drug resistant bacterial strains and disease complication in return. ${ }^{5,6,7}$

Bacteriology of CSOM can also be differentiated from AOM on bacteriological grounds. In AOM the bacteria found in the middle ear include Streptococcus pneumoniae, Staphylococcus aureus, Haemophilusinfluenzae and Micrococcus catarrhalis. ${ }^{8,9}$ These are respiratory pathogens that may have been insufflated from the nasopharynx into the middle ear through the Eustachian tube during bouts of upper respiratory infections. In CSOM the bacteria may be aerobic (e.g. Pseudomonas aeruginosa, Escherichia coli, S. aureus, Streptococcus pyogenes, Proteus mirabilis, Klebsiella species) or anaerobic (e.g. Bacteroides, Peptostreptococcus, Proprionibacterium). The bacteria are infrequently found in the skin of the external canal, but may proliferate in the presence of trauma, inflammation, lacerations or high humidity. ${ }^{10}$ These bacteria may 
then gain entry to the middle ear through a chronic perforation. Among these bacteria, P. aeruginosa has been particularly blamed for the deep-seated and progressive destruction of middle ear and mastoid structures through its toxins and enzymes. The knowledge of the prevalence of the organism and sensitivity to antibiotics of that organism and also availability of the antibiotics is very important for dispensing medical treatment for discharging ears. Hence, the periodic update of prevalence and antibiogram of the etiological agents for CSOM would be helpful in therapy and management of patients. ${ }^{11,12}$

\section{Materials And Methods:}

This is a prospective type of hospital based study wherein a total of 100 clinically diagnosed patients with chronic suppurative otitis media in active stage of the disease were selected. This study included patients attending ENT OPD at Bhaskar Medical College/General Hospital, Yenkapally village in the Moinabadmandal, Telangana State covering the whole belt of moinabad which includes about 26 villages over 1 year period from Jan 2015 to Jan 2016.

\section{Inclusion Criteria:}

1. Chronic suppurative otitis media in active state.i.e. when discharge is present. It could be either tubotympanic or atticoantral type of disease.

2. Patients of any age.

3. Unilateral as well as bilateral csom

4. Post operative discharging ears.

\section{Exclusion Criteria:}

1. Patients on medications either systemic or topical prior to sterile swab collection, atleast a week.

\section{Method Of Collection Of Pus And Analysis:}

It was collected with the help of sterile culture swabs. Separate swabs for each ear in case of bilateral disease. . The samples were immediately sent to the microbiology laboratory for bacterial studies. In the laboratory, the ear discharges were collected and examined microscopically. For bacterial isolation, the samples were inoculated on Blood agar, MacConkey's agar and Chocolate agar media and were incubated at $37^{\circ} \mathrm{C}$ for 24 hours. The antimicrobial susceptibility of the bacterial isolates was assessed by the Kirby- Bauer's disc diffusion method. ${ }^{13}$

\section{Observation And Results:}

Among 100 patients selected for the study, 51\% were male and $49 \%$ female. The overall percentage of children in this study was $7 \%$. Age wise analysis of the data showed that maximum number of patients were in the age group of 21-30 years (33\%), followed by $16 \%$ in the age group of 31-40 years and 41 to 50 years. Following are the tabular forms and bar diagram for age and sex distribution.

Table 1: Sex Distribution

\begin{tabular}{|c|c|}
\hline & $\%$ \\
\hline Male & 51 \\
\hline Female & 49 \\
\hline Total & 100 \\
\hline
\end{tabular}

\section{Sex distribution}

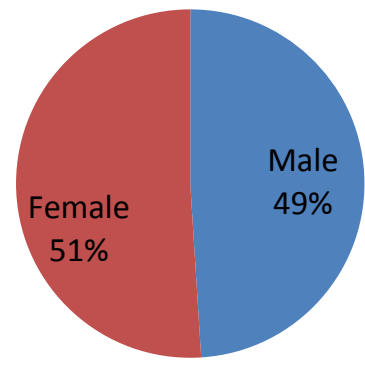

Fig 1 showing sex distribution 
Table 2: Age Distribution

\begin{tabular}{|c|c|c|}
\hline In years & No.of patients & $\%$ \\
\hline $1-10$ & 7 & 7 \\
\hline $11-20$ & 14 & 14 \\
\hline $21-30$ & 33 & 33 \\
\hline $31-40$ & 16 & 16 \\
\hline $41-50$ & 16 & 16 \\
\hline $51-60$ & 8 & 8 \\
\hline $61-70$ & 6 & 6 \\
\hline
\end{tabular}

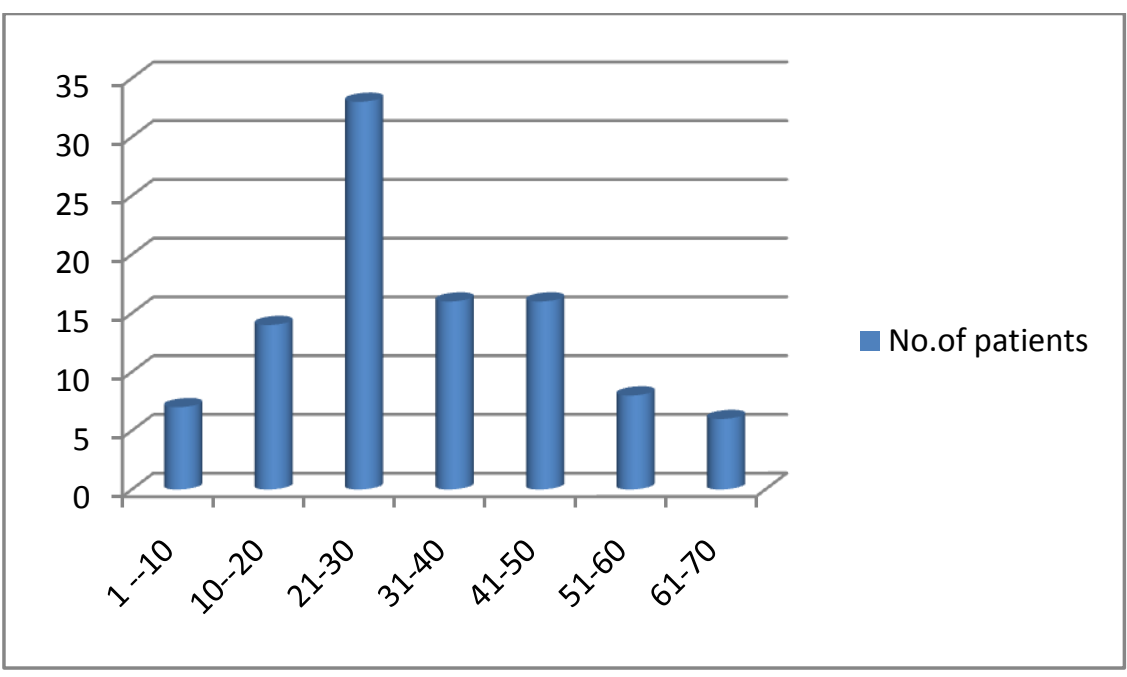

Fig 2 showing age distribution

Table 3: Laterality Of The Disease

\begin{tabular}{|c|c|c|}
\hline & No. of patients & $\%$ \\
\hline Right ear & 37 & 37 \\
\hline Left ear & 51 & 51 \\
\hline Bilateral & 12 & 12 \\
\hline
\end{tabular}

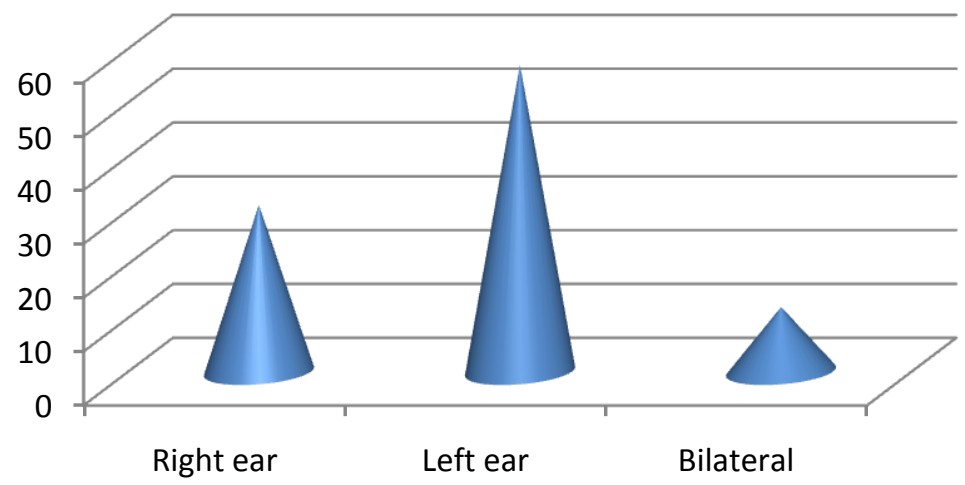

Fig 3 showing laterality of the disease

Table 4: Organism Isolated

\begin{tabular}{|c|c|c|}
\hline & No.of patients & $\%$ \\
\hline No organism isolated & 24 & 24 \\
\hline Pseudomonas aeruginosa & 25 & 25 \\
\hline Staphylococcus aureus & 24 & 24 \\
\hline Klebsiella & 7 & 7 \\
\hline E.coli & 7 & 5 \\
\hline Streptococcus pneumonia & 5 & 4 \\
\hline Proteus species & 4 & 3 \\
\hline Aspergillus niger & 3 & 1 \\
\hline Citrobacter & 1 & \\
\hline
\end{tabular}




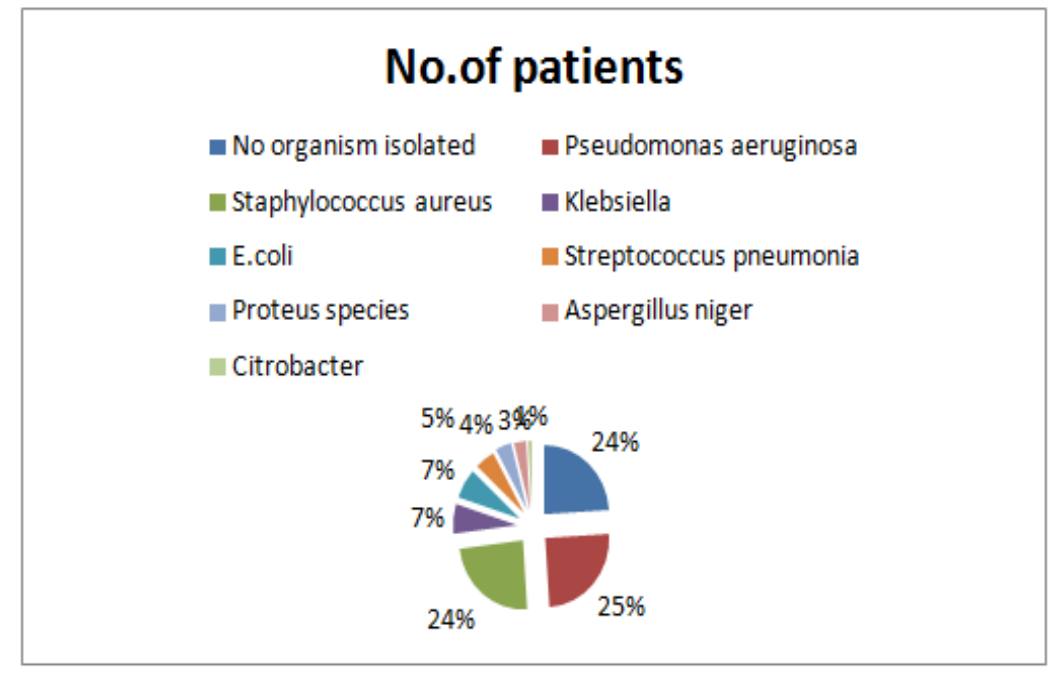

Fig 4 showing \% of organism isolated

Table 5: Antibiotic Sensitivity Pattern In Organisms Isolated

\begin{tabular}{|c|c|c|c|c|c|c|c|c|c|c|c|c|c|c|c|c|c|c|c|}
\hline & l.A & $2 . G$ & 3.0 & 4.Cflxon & $\begin{array}{l}\text { 5.Lflx } \\
\square\end{array}$ & $7 . \mathrm{Az}$ & $\begin{array}{l}9 . \mathrm{Am} \\
p\end{array}$ & $\begin{array}{l}10 \mathrm{~A} \\
\text { mpt } \\
8\end{array}$ & $\begin{array}{l}\text { 11.Am } \\
\text { oxycla } \\
v\end{array}$ & $12 . \mathrm{P}$ & $\begin{array}{l}13 . p+t z \\
b\end{array}$ & $\begin{array}{l}14 . \\
\text { E }\end{array}$ & $\mathrm{C}-1$ & $\mathrm{C}-2$ & $C-3$ & $\mathrm{C} 4$ & C.5 & $c-6$ & C.7 \\
\hline $\begin{array}{l}\text { Pradomonas } \\
\text { Aenuginosa }\end{array}$ & $73.63 \%$ & $\begin{array}{l}57.71 \\
\%\end{array}$ & $37.81 \%$ & $95.52 \%$ & $\begin{array}{l}19.9 \\
\%\end{array}$ & $1.99 \%$ & & & $3.98 \%$ & $9.95 \%$ & $33.83 \%$ & $\begin{array}{l}5.97 \\
\%\end{array}$ & $\begin{array}{l}3.98 \\
\%\end{array}$ & 7.96 & & $\begin{array}{l}11.9 \\
4\end{array}$ & & $1.99 \%$ & $\begin{array}{l}29.85 \\
\%\end{array}$ \\
\hline $\begin{array}{r}\text { Staphylococcus } \\
\text { Aureus }\end{array}$ & $79.64 \%$ & $\begin{array}{l}66.32 \\
\%\end{array}$ & $18.8 \%$ & $75.12 \%$ & 8.80 & $5.28 \%$ & $1.76 \%$ & $\begin{array}{l}1.76 \\
\%\end{array}$ & $7.04 \%$ & & $5.28 \%$ & $\begin{array}{l}15.8 \\
4 \% \\
\end{array}$ & $\begin{array}{l}8.8 \\
\%\end{array}$ & $\begin{array}{l}12.3 \\
2 \%\end{array}$ & $\begin{array}{l}10.5 \\
6 \%\end{array}$ & $\begin{array}{l}5.28 \\
\%\end{array}$ & $1.76 \%$ & & 22.88 \\
\hline Klebsiella & $12.81 \%$ & $4.27 \%$ & $1.83 \%$ & $2.44 \%$ & $\begin{array}{l}1.22 \\
\%\end{array}$ & & & & & & $1.22 \%$ & & & & $\begin{array}{l}1.22 \\
\%\end{array}$ & & & & $\begin{array}{l}12.20 \\
\%\end{array}$ \\
\hline E. Coli & $9.28 \%$ & $3.48 \%$ & $3.48 \%$ & $11.63 \%$ & $\begin{array}{l}1.63 \\
\%\end{array}$ & $0.58 \%$ & & & & & & & $\begin{array}{l}0.58 \\
\%\end{array}$ & & & & $0.58 \%$ & & $2.32 \%$ \\
\hline $\begin{array}{l}\text { Streptococous } \\
\text { Pnemononis }\end{array}$ & $7.149 \%$ & $4.599 \%$ & & $11.22 \%$ & & $10.2 \%$ & & $\begin{array}{l}0.51 \\
\%\end{array}$ & $0.51 \%$ & & & & & & $\begin{array}{l}2.16 \\
\%\end{array}$ & & & & \\
\hline $\begin{array}{r}\text { Protels } \\
\text { Sp. }\end{array}$ & $3.60 \%$ & $0.72 \%$ & & $2.52 \%$ & & & & & & & & & $\begin{array}{l}0.36 \\
\%\end{array}$ & & & $\begin{array}{l}0.36 \\
\%\end{array}$ & & & $1.44 \%$ \\
\hline Citrobaster & $0.28 \%$ & & & $0.56 \%$ & $\begin{array}{l}0.28 \\
\%\end{array}$ & & & & & & & & $\begin{array}{l}0.14 \\
\%\end{array}$ & $\begin{array}{l}0.14 \\
\%\end{array}$ & & & & & $0.56 \%$ \\
\hline
\end{tabular}

1. A- Amikacin

5. Lvfxcn- Levofloxacin

8.Amp+S- Ampicillin+Sulbactum

9. Amoxyclav- Amoxycillin+ Clavulanic acid

11. P+tzb - Pipercillin + Tazobactum

C-1 Ceftriazone

C-4 Cefoxitim
2. G- Gentamicin

6. A- Azithromycin
3. O- Oflaxacin

7.Amp- Ampillicin
4. Cflxn- Ciprofloxacin

10. P- Pipercillin

12. E- Ertapenam

C-3 Cefixime

C-6 Cefaperazone+Sulbactum

\section{Discussion}

In the present study, the age distribution was more in the age group 21-30years, followed by $31-40$ years and 41- 50 years. Females were more affected than males. Children were $7 \%$ in our study. Though unimportant is the laterality of the disease, Left ear discharges were more than right and $12 \%$ showed bilateral disease. In the present study, the analysis of our data showed the prevalence of gram negative organisms over gram positive, pseudomonas aeruginosa being commonest followed closely by staphylococcus aureus. In nearly about 24 of the cases, no organism was isolated. In accordance with our studies, studies done by 
Harvinderkumar and Sonia seth ${ }^{9}$ et al concluded pseudomonas(25\%) and staphylococcus aureus(24\%) as the most commonly isolated from ear discharges. Similarly Loy et $\mathrm{al}^{14}$, Mansoor et al ${ }^{15}$ goes well with our study. In contrast to our study, Adoga et al showed Klebsiella as the most commonly isolated organism. ${ }^{16}$ The other organisms isolated in the decreasing frequency in our study are Klebsiella(7\%), E.Coli(7\%), Streptococcus Pneumonia(5\%), Proteus sp and Citrobacter.

The most commonly isolated organism ,Psedomonas is highly sensitive Ciproflaxacin $(95.52 \%)$ followed Amikacin(73.6\%), Gentamicin(57.7\%), Ofloxacin(37.81\%), Pipercillin + Tazobactum (33.38\%) and Cefaperazone + Sulbactum(29.38\%). Where as Staphylococcus Aureus which was 24\% isolated in culture showed sensitivity to Amikacin(79.64\%), Ciprofloxacin (75.12\%), Gentamycin(66.32\%), Cefaperazone and sulbactum(22.88\%) andOfloxacin (18.8\%).Klebsiella and E.coli showed maximum sensitivity to Ciproflaxacin, Oflaxacin and Cefotaxime.Streptococcus Pneumoniae showed sensitivity to Cefotaxime, Ciprofloxacin and Amikacain. Overall sensitivity pattern seen in this study is for Ciprofloxacin and Amikacin, followed by Gentamicin, Cefaperazone + Sulbactum and Cefotaxime.

This pattern of sensitivity seen in this study is in accordance to H. Kumar and S.Sethet $\mathrm{al}^{9}$ studies where amikacin and ciprofloxacin are the most effective antibiotics. Other studies in accordance are Lee and Park et $\mathrm{al}^{17}$, Sharma and Agarwal et $\mathrm{al}^{18}$ and Deb and Ray et al ${ }^{19}$. On the contrary, studies like Nwankwo and Salisu et $\mathrm{al}^{20}$ showed oflaxacin , gentamicin and ceftazidime as the most sensitive drug.

\section{Conclusion}

This study concludes that Pseudomonas is the most common organism isolated in the culture of the discharges in CSOM, followed closely by Staphylococcus aureus. Ciproflaxacin is the most sensitive drug which can be given as first line of treatment in CSOM . Amikacin is also equally effective but being more ototoxic and available as only injectable form. Ciprofloxacin either oral or topical becomes a more preferred option. To our surprise, the most commonly prescribed antibiotic Amoxycillin with clavulanic acis was found to be least effective.Incidentally this antibiotic enjoys high patronage by general duty physicians, being the most often prescribed empirical antibiotic in CSOM .Azithromycin and erythromycin was also found to be not so effective as per this study in CSOM cases.Cephalosporins, belongin to any generation are quite effective and good choice of drugs for actively discharging ears.

\section{References}

[1]. FT Orji and BO Dike, Observations on the Current Bacteriological Profile of Chronic Suppurative Otitis Media in South Eastern Nigeria, Annuals of Medical Health Sciences Research, 2015 Mar-Apr; 5(2): 124-128.

[2]. Monasta L, Ronfani L, Marchetti F, Montico M, VecchiBrumatti L, Bavcar A, et al. Burden of disease caused by otitis media: Systematic review and global estimates. PLoS One. 2012;7:e36226.

[3]. Acuin J. Chronic suppurative otitis media: Burden of illness and management options. Geneva, Switzerland: World Health Organization; 2004

[4]. Mohammed JamiuKazeem, RuqayyahAiyeleso, Current bacteriological profile of chronic suppurative otitis media in a tertiary facility of Northern Nigeria, Indian Journal of Otology, 2016, vol 2, Issue 3, Pg 157-161.

[5]. Hassan O, Adeyemi A study of bacterial isolates in cases of otitis media in patients attending Oautch, Ile-Ife. Afr J ExpMicrobiol. 2007;8:130-6.

[6]. Olusanya BO, Newton VE. Promoting a global health agenda for permanent childhood hearing impairment. Comm Ear Hearing H. 2007;4(6):25-27.

[7]. Morris PS, Leach AJ. Prevention and management of chronic suppurative otitis media in aboriginal children: A practical approach. Comm Ear Hearing H. 2007;4:22-5.

[8]. Bluestone CD. Epidemiology and pathogenesis of chronic suppurative otitis media: implications for prevention and treatment. Int $\mathbf{J}$ PediatrOtorhinolaryngol 1998;42:207-23.

[9]. Kumar H, Seth S. Bacterial and fungal study of 100 cases of chronic suppurative otitis media. J ClinDiagn Res. 2011;5:1224-7.

[10]. Shenoi PM. Management of chronic suppurative otitis media. Scott Brown's textbook of Otorhinolaryngology. 5th Edition. 1988; 3 : 215.

[11]. Adoga A, Nimkur T, Silas O. Chronic suppurative otitis media: Socio-economic implications in a tertiary hospital in Northern Nigeria. Pan Afr Med J. 2010;4:3.

[12]. Nwabuisi C., Ologe FE. Pathogenic agents of Chronic Suppurative Otitis Media in Ilorin, Nigeria. East African Medical Journal, 2002; 79(4): $202-205$.

[13]. Collee JG, Duguid JP, Fraser AG, Marmion BP, Simmons A. Laboratory strategy in the diagnosis of infective syndromes. Mackie and McCartney Practical Medical Microbiology. Churchill Livingstone: Singapore. 14th ed. 1996: 53-94.

[14]. Loy AH, Tan AL, Lu PK. Microbiology of chronic suppurative otitis media in Singapore. Singapore Med J 2002;43:296-9.

[15]. Mansoor T, Musani MA, Khalid G, Kamal M. Pseudomonas aeruginosa in chronic suppurative otitis media: Sensitivity spectrum against various antibiotics in Karachi. J Ayub Med Coll Abbottabad 2009;21:120-3.

[16]. Adoga AA, Bakari A, Afolabi OA, Kodiya AM, Ahmad BM. Bacterial isolates in chronic suppurative otitis media: A changing pattern? Niger J Med 2011;20:96-8.

[17]. Lee SK, Park DC, Kim MG, Boo SH, Choi YJ, Byun JY, et al. Rate of isolation and trends of antimicrobial resistance of multidrug resistant pseudomonas aeruginosa from otorrhea in chronic suppurative otitis media. ClinExpOtorhinolaryngol. 2012;5:17-22.

[18]. Sharma K, Aggarwal A, Khurana PM. Comparison of bacteriology in bilaterally discharging ears in chronic suppurative otitis media. Indian J Otolaryngol Head Neck Surg. 2010;62:153-7.

[19]. Deb T, Ray D. A study of the bacteriological profile of chronic suppurative otitis media in agartala. Indian J Otolaryngol Head Neck Surg. 2012;64:326-9.

[20]. Nwankwo EO, Salisu AD. Bacteriology of chronic discharging ears of patients in Kano, Nigeria. J Med Lab 2005;49:57. 